\title{
Pengaruh Inflasi, Indeks Produksi Industri, dan Kurs terhadap Penghimpunan Zakat, Infaq, dan Sedekah
}

\author{
Dina Islamiyati ${ }^{\bowtie}$, Ira Humaira Hany \\ Mahasiswa Program Studi S2 Ekonomi Islam-Fakultas Ekonomi dan Bisnis \\ Universitas Airlangga \\ e-mail: dina.islamiyati-2018@pasca.unair.ac.id
}

\begin{abstract}
This study aims to determine the effect of inflation, Industrial Production Index (IPI), and exchange rates on the collection of ZIS - zakat, infaq and shodaqoh (alms)-in BAZNAS period of 2014-2018 using Autoregressive Distributed Lag (ARDL). The results show that only the IPI variable has a significant effect on ZIS fund collection, while inflation and exchange rates variables do not have significant effect. However, all variables have been indicated as having long-run cointegration or long-run simultaneously effect by looking at the result of the $F$-statistic value that is greater than the upper bounds.
\end{abstract}

Keywords: ZIS collection, inflation, Industrial Production Index, exchange rate, ARDL

\begin{abstract}
Abstrak
Penelitian ini bertujuan untuk mengetahui pengaruh inflasi, Indeks Produksi Industri (IPI), dan kurs terhadap penghimpunan zakat, infaq, dan sedekah (ZIS) di BAZNAS tahun 2014-2018 menggunakan Autoregressive Distributed Lag (ARDL). Hasil penelitian menunjukkan bahwa hanya variabel IPI yang berpengaruh signifikan terhadap penghimpunan dana ZIS. Variabel Inflasi dan kurs berpengaruh tidak signifikan. Namun, semua variabel memiliki kointegrasi jangka panjang atau bergerak bersama-sama dalam jangka panjang dengan melihat hasil dari nilai F-statistik yang lebih besar dari upper bounds.
\end{abstract}

Kata kunci: Penghimpunan ZIS, inflasi, Indeks Produksi Industri, kurs, ARDL

\section{PENDAHULUAN}

Angka kemiskinan di Indonesia pada semester 2 tahun 2019 yang diukur melalui pendekatan kemampuan masyarakat dalam memenuhi kebutuhan makanan dan bukan makanan adalah sebesar 9,22\%. Angka ini diperoleh dari rata-rata pengeluaran perkapita masyarakat yang berada di bawah garis kemiskinan (bps.go.id). Indonesia juga memiliki masalah ketimpangan. Berdasarkan ukuran ketimpangan Bank Dunia, distribusi pengeluaran pada kelompok 40 persen terbawah adalah sebesar 17,71 persen. Hal ini berarti pengeluaran penduduk pada Maret 2019 berada pada kategori tingkat 
ketimpangan rendah. Jika dirinci menurut wilayah, di daerah perkotaan angkanya tercatat sebesar 16,93 persen yang berarti tergolong pada kategori ketimpangan sedang. Sementara untuk daerah perdesaan, angkanya tercatat sebesar 20,59 persen, yang berarti tergolong dalam kategori ketimpangan rendah (bps.go.id).

Berdasarkan Badan Pusat Statistik (BPS) (2019), 87\% masyarakat Indonesia adalah pemeluk agama Islam. Islam mengajarkan pemeluknya untuk wajib mengeluarkan sebagian hartanya di jalan Allah SWT dengan cara berzakat sebagai inklusi islam untuk mendistribusikan harta kekayaan umat sebagaimana telah dijelaskan dalam Al Quran surat Al Hasr (59): 7 bahwa;

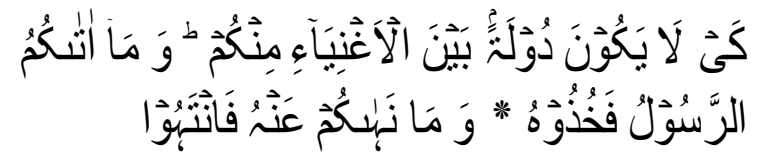

Artinya: " "....supaya harta itu jangan beredar di antara orang-orang kaya saja di antara kamu, apa yang diberikan Rasul kepadamu, maka terimalah. Dan apa yang dilarangnya bagimu, maka tinggalkanlah...."

Fenomena tersebut menyiratkan bahwa Indonesia memiliki potensi pendistribusian kekayaan yang sangat besar melalui zakat, sehingga sangat mungkin kemiskinan dan ketimpangan Indonesia dapat teratasi dengan baik. Berdasarkan Keputusan Presiden RI No. 8 Tahun 2001, Indonesia memiliki Badan Amil Zakat Nasional (BAZNAS) yang merupakan badan resmi dan satusatunya yang dibentuk oleh pemerintah yang memiliki tugas dan fungsi menghimpun dan menyalurkan zakat, infaq, dan sedekah (ZIS) pada tingkat nasional.

Penghimpunan ZIS tidak serta merta berjalan dengan lancar. Beberapa faktor mampu mempengaruhi penghimpunan maupun pendistribusian kekayaan masyarakat seperti halnya inflasi, indeks produksi distribusi, dan kurs rupiah terhadap US dollar yang memiliki pengaruh terhadap pendapatan masyarakat. Berdasarkan pendahuluan di atas, rumusan masalah penelitian ini adalah untuk mengetahui apakah faktor makroekonomi seperti: inflasi, Indeks Produksi Industri, dan nilai tukar berpengaruh terhadap jumlah penghimpunan ZIS di BAZNAS.

\section{Inflasi}

Inflasi adalah adanya kecenderungan kenaikan harga-harga secara umum dan terus-menerus. Yang dimaksud inflasi di sini merupakan kenaikkan harga yang sangat besar sehingga menyebabkan kenaikan pada sebagian besar harga dari barang lain. Jadi, apabila kenaikan barang hanya dari satu atau dua barang saja tidak dapat disebut dengan inflasi (Susanto dkk., 2018). Adapun beberapa faktor penyebab terjadinya inflasi yakni: penurunan nilai tukar mata uang, semakin banyaknya jumlah uang beredar, tingginya permintaan suatu barang, dan lain-lain (Rumate \& Engka, 2019). Inflasi juga dapat diartikan sebagai perkembangan perekonomian yang menjadikan harga dan gaji meningkat, permintaan tenaga kerja melebihi penawaran, dan jumlah uang beredar sangat banyak. Tanda-tanda adanya inflasi yakni kenaikan harga barang secara terus menerus dalam rata-rata tingkat harga merupakan fenomena ekonomi yang berdampak positif atau negatif terhadap perekonomian (Del Rosa dkk., 2019).

\section{Kurs}

Kurs atau nilai tukar merupakan pembanding antara nilai/harga mata uang suatu negara dengan negara lain. Nilai tukar menggambarkan tentang seimbangnya antara penawaran dan permintaan terhadap mata uang dalam negeri maupun mata uang asing. Menurunnya nilai tukar rupiah mencerminkan menurunnya sebuah permintaan masyarakat terhadap mata uang 
Pengaruh Inflasi, Indeks Produksi Industri, dan Kurs terhadap... (Dina Islamiyati, Ira Humaira Hany)

rupiah karena melemahnya perekonomian nasional atau karena tingginya permintaan mata uang asing yang digunakan untuk alat transaksi internasional (Triyono, 2008).

Nilai tukar merupakan nilai suatu mata uang terhadap mata uang negara asing. Pertukaran mata uang asing dalam pasar terjadi secara fisik dan struktur institusi di mana mata uang suatu negara ditukarkan dengan mata uang negara lain yang sudah ditentukan dan transaksi ini dilakukan secara sempurna. Berdasarkan sistem moneter internasional teknik penetapan nilai tukar mata uang ada tiga (Prakoso, 2007), berikut penjelasannya:

1. Fixed exchange rate system (nilai tukar stabil)

2. Floating exchange rate system (sistem nilai tukar mengambang yang disesuaikan dengan permintaan atau penawaran terhadap mata uang tersebut)

3. Pegged exchange rate system (sistem nilai tukar mata uang yang dilakukan dengan menghubungkan nilai mata uang suatu negara dengan nilai mata uang negara lain atas sejumlah mata uang tertentu)

Untuk negara Indonesia sendiri menganut sistem bebas mengambang (floating exchange rate). Di mana hal ini akan sering berubah sesuai dengan permintaan atau penawaran nilai mata uang terhadap rupiah. Banyaknya bahan baku yang didapat dari impor seperti kebutuhan pokok atau minyak dan lain-lain menjadikan indikator nilai mata uang rupiah terhadap dolar digunakan.

\section{Indeks Produksi Industri}

Indeks produksi industri merupakan indikator dalam ekonomi yang dibuat oleh dewan US Federal Reserve Bank, untuk mengukur berubahnya nilai total inflasi yang disesuaikan dengan output produksi dari produsen, perusahaan pertambangan listrik, pasokan air, dan industri gas. IPI dibentuk untuk mengukur kenaikan dan penurunan hasil produksi (Isnan, 2017).

IPI menggambarkan tingkat produktifitas masyarakat menentukan seberapa banyak zakat yang akan ditunaikan. Pertumbuhan IPI merupakan proksi dari pertumbuhan ekonomi yang dapat meningkatkan pendapatan nasional. Hal tersebut juga meningkatkan pendapatan masyarakat sehingga masyarakatpun mampu untuk berzakat infak sedekah.

\section{Penghimpunan Dana ZIS}

$\begin{array}{crrr}\text { Zakat } & \text { secara } & \text { istilah adalah } \\ \text { membersihkan } & \text { diri, } & \text { dengan artian }\end{array}$ membersihkan diri dengan harta benda yang dikeluarkan untuk menunaikan zakat. Sehingga dalam diri tumbuhlah rasa dermawan dan menghilangkan dari sifat kikir maupun mementingkan diri sendiri. Dalam firman Allah disebutkan dalam QS. At-Taubah yang artinya:

"ambillah zakat dari sebagian harta mereka, dengan zakat itu kamu akan membersihkan dan mensucikan mereka dan berdoalah untuk mereka. Sesungguhnya doa kamu itu (menjadi) ketenteraman jiwa bagi mereka, dan Allah Maha Mendengar lagi Maha Mengetahui"

Zakat menjadi sebuah instrumen yang sangat penting dalam Islam dan salah satu rukun Islam yang menjadi alat redistribusi kekayaan yang mempunyai tujuan untuk menyejahterahkan umat Islam. Zakat yang dikelola dengan baik akan mampu menurunkan tingkat kesenjangan ekonomi masyarakat.

Pada konsep Islam, zakat menjadi salah satu pendapatan negara. Oleh karena itu, zakat sangatlah penting bagi keberlangsungan kehidupan dan untuk mencapai tujuan bersama. Melihat betapa pentingnya arti zakat pembahsan tentang penghimpunan zakatpun sangatlah banyak dari berbagai 
argumen yang menjadi perhatian menarik. Banyak para ahli yang mencoba menyusun suatu metode yang menggunakan instrumen instrumen tertentu untuk memprekdiksi penghimpunan atau perolehan zakat (Aziz dkk, 2017).

Pemberdayaan melalui potensi zakat di Indonesia ini sangatlah besar, karena Indonesia merupakan negara yang mayoritas muslim dengan penduduk muslim terbesar di dunia. Sebagaimana yang telah disyariatkan, Indonesia memiliki tanggung jawab moral untuk melaksanakan kewajiban membayar zakat yang hukumnya wajib bagi setiap muslim. Tujuan dari adanya filantropi Islam salah satunya yakni untuk mensejahterahkan kehidupan Umat. Dengan penerimaan dan pendistribusian dana ZIS dengan baik dapat mendorong kesejahteraan masyarakat.

\section{METODE PENELITIAN}

Penelitian menggunakan data sekunder. Data bulanan time series dari IPI, inflasi, kurs, dan penghimpunan dana ZIS diperoleh dari BPS, BI, dan BAZNAS periode 2014-2018. Metode analisis data yang digunakan dalam penelitian yakni kuantitatif dengan analisis deskriptif yang menggunakan metode Vector Auto Regression (VAR). Apabila uji akar unit stasioner pada ordo level maka menggunakan Vector Auto Regression (VAR). Apabila stasioner pada ordo berbeda yakni level dan juga pada first different maka menggunakan Autoregressive Distributed Lag (ARDL). Apabila stasioner pada fisrt different saja maka menggunakan Vector Error Correction Model (VECM). Variabel endogen dalam penenlitian ini yakni penerimaan ZIS, sedangkan variabel eksogennya yakni inflasi, kurs, dan IPI. Model kerangka pemikiran penelitian ini dapat dilihat pada Gambar 1.

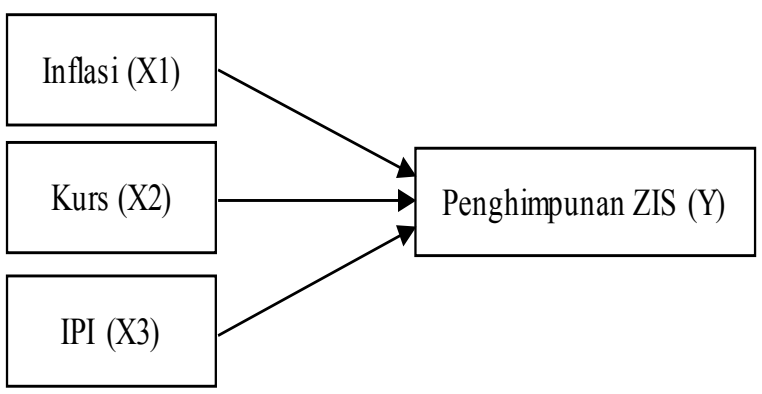

Gambar 1. Model Kerangka Pemikiran

\section{HASIL DAN PEMBAHASAN}

Sebagaimana langkah-langkah yang disebutkan pada metode penelitian, maka akan dilakukan analisis sebagai berikut.

\section{Uji Stasioneritas}

Langkah awal untuk menentukan metode yang akan digunakan pada data time series adalah dengan melihat hasil uji stasioneritas. Pada penelitian ini untuk mengetahui stasioneritas data adalah dengan menggunakan uji akar unit (unit root test). Tipe uji penelitian ini menggunakan individual akar-fisher- Augmented DickeyFulleer (ADF) pada level I(0) yang kemudian akan dilanjutkan pada first different I(1) apabila ada variabel tidak stasioner pada level. Menurut Tanjung \& Devi (2018) data dapat dikatakan stasioner apabila nilai probabilitas pada tipe uji ADF lebih kecil dari Mackinnon Critical Value 5\% yang menunjukan bahwa H0 gagal ditolak. Artinya tidak ada bukti bahwa didalam persamaan mengandung akar-akar unit yang dapat dikatakan bahwa data tidak stasioner. Data yang stasioner adalah apabila pada persamaan mengandung akar-akar unit. Tabel 2 menampilkan hasil analisis uji akar unit. 
Pengaruh Inflasi, Indeks Produksi Industri, dan Kurs terhadap... (Dina Islamiyati, Ira Humaira Hany)

Tabel 1. Definisi Operasional Variabel

\begin{tabular}{|c|c|c|}
\hline Variabel & Definisi & Sumber \\
\hline $\begin{array}{l}\text { Zakat, Infaq, } \\
\text { Sedekah (Y) }\end{array}$ & $\begin{array}{l}\text { Data ZIS yang digunakan dalam penelitian ini adalah } \\
\text { nominal penghimpunan Zakat Infaq dan Sedekah di } \\
\text { BAZNAS setiap bulan, dimulai tahun 2014-2018. }\end{array}$ & $\begin{array}{l}\text { Badan Amil Zakat Nasional https:// } \\
\text { baznas.go.id/ }\end{array}$ \\
\hline Inflasi (X1) & $\begin{array}{l}\text { Data Inflasi yang digunakan adalah persentase inflasi } \\
\text { (Indeks Harga Konsumen) berdasarkan perhitungan } \\
\text { inflasi tahunan, data yang diambil adalah bulanan. }\end{array}$ & Bank Indonesia (www.bi.go.id) \\
\hline $\begin{array}{l}\text { Indeks Produksi } \\
\text { Distribusi (X2) }\end{array}$ & $\begin{array}{l}\text { Data yang digunakan adalah indeks produksi industri } \\
\text { besar dan sedang, tahun } 2014-2018 \text {. }\end{array}$ & $\begin{array}{l}\text { Badan Pusat Statistik (https://www. } \\
\text { bps.go.id/) }\end{array}$ \\
\hline Kurs (X3) & $\begin{array}{l}\text { Data yang digunakan adalah nominal kurs Rupiah } \\
\text { terhadap US Dollar setiap bulan mulai dari tahun } \\
\text { 2014-2018. }\end{array}$ & Bank Indonesia (www.bi.go.id) \\
\hline
\end{tabular}

Tabel 2. Hasil Uji Stasioneritas, Uji Akar Unit pada Level I(0)

\begin{tabular}{lcl}
\hline \multicolumn{1}{c}{ Series } & Prob. & Keterangan \\
\hline LNZIS & 0.0010 & Stasioner \\
INFLASI & 0.2345 & Tidak Stasioner \\
LNIPI & 0.7433 & Tidak Stasioner \\
KURS & 0.6424 & Tidak Stasioner \\
\hline
\end{tabular}

Sumber: data diolah peneliti, 2019

Tabel 2 menunjukan hasil analisis uji stasioneritas menggunakan uji akar unit pada level. Hasil menunjukan bahwa probabilitas zakat, infaq, dan sedekah yang dituliskan dengan LNZIS pada Tabel 2 lebih kecil dari Mackinnon Critical Value 5\% $(0,0010<0,05)$ yang artinya ZIS stasioner pada level. Probabilitas inflasi lebih besar dari Mackinnon Critical Value 5\% (0,2345 $>0,05)$ yang artinya inflasi tidak stasioner pada level. Probabilitas indeks produksi industri yang dituliskan dengan LNIPI pada Tabel 2 lebih besar dari Mackinnon Critical Value $5 \%(0,7433>0,05)$ yang artinya indeks produksi industri tidak stasioner pada level. Probabilitas kurs lebih besar dari Mackinnon Critical Value 5\% (0,6424 > $0,05)$ yang artinya kurs tidak stasioner pada level. Hasil uji stasioneritas menggunakan uji akar unit menunjukkan bahwa hanya ada satu variabel (ZIS) yang stasioner pada level. Artinya adalah ada bukti bahwa di dalam persamaan tersebut mengandung akar-akar unit. Dapat dikatakan bahwa data tidak stasioner pada level, sehingga data time series perlu dilanjutkan untuk diidentifikasi uji stasioneritas menggunakan uji akar unit pada tingkat first different.

Tabel 3. Hasil Uji Stasioneritas, Uji Akar unit pada Level I(1)

\begin{tabular}{lcl}
\hline \multicolumn{1}{c}{ Series } & Prob. & \multicolumn{1}{c}{ Keterangan } \\
\hline D(LNZIS) & 0.0000 & Stasioner \\
D(INFLASI) & 0.0000 & Stasioner \\
D(LNIPI) & 0.0000 & Stasioner \\
D(KURS) & 0.0000 & Stasioner \\
\hline
\end{tabular}

Sumber: data diolah peneliti, 2019

Tabel 3 menunjukkan hasil analisis uji stasioneritas menggunakan uji akar unit pada first different. Hasil menunjukkan bahwa probabilitas zakat, infaq dan sedekah yang dituliskan dengan D(LNZIS) pada Tabel 3 lebih kecil dari Mackinnon Critical Value 5\% $(0,0000<0.05)$ yang artinya ZIS stasioner pada first different. Probabilitas inflasi lebih kecil dari Mackinnon Critical Value $5 \%(0,0000<0,05)$ yang artinya inflasi stasioner pada first different. Probabilitas indeks produksi industri yang dituliskan dengan D(LNIPI) pada Tabel 3 lebih kecil dari Mackinnon Critical Value 5\% $(0,0000<$ $0,05)$ yang artinya indeks produksi industri stasioner pada first different. Probabilitas 
kurs lebih kecil dari Mackinnon Critical Value $5 \%(0,0000<0,05)$ yang artinya kurs stasioner pada first different.

Hasil analisis menunjukkan bahwa terdapat variabel yang stasioner pada level dan beberapa variabel lainya stasioner pada first different. Hal ini menunjukkan bahwa data stasioner pada ordo yang berbeda. Dengan demikian, penelitian ini akan menggunakan model Autoregresif Distributed Lag (ARDL) (Tulak dkk., 2017). Langkah selanjutnya adalah mengetahui panjang lag yang digunakan untuk mengolah data.

\section{Uji Lag Optimum}

Pemilihan jumlah lag digunakan untuk memilih seberapa besar jumlah lag yang digunakan dalam penelitian, sehingga pemilihan jumlah lag optimum sangat diperlukan agar diperoleh hasil yang lebih baik. Menurut Tanjung \& Devi (2018), uji Lag Optimum menunjukkan panjang lag. Pada uji ini, apabila lag yang dihasilkan terlalu sedikit maka residual dari regresi tidak akan menampilkan proses white noise sehingga model tidak dapat secara tepat mengestimasi actual error. Apabila lag yang dihasilkan terlalu banyak akan menyebabkan adanya pengurangan kemampuan untuk menolak $\mathrm{H}_{0}$ karena tambahan parameter yang banyak akan mengurangi degrees of freedom. Selain itu, uji lag juga digunakan untuk melihat lama periode suatu variabel yang dipengaruhi variabel masa lalunya dan variabel endogen lainnya. Penelitian ini akan melihat jumlah lag optimum berdasarkan hasil lag length criteria VAR yang ditunjukkan oleh kriteria model LR (squential modified LR test statistic), FPE (Final Prediction Error), AIC (Akaike Information Criterian), SC (Schwarz Information Criterion), HQ (Hannan-Quinn Information Criterion) dengan melihat sebaran tanda bintang (*) terbanyak yang terdapat pada tingkatan lag.

Berdasarkan Tabel 4, hasil uji lag optimum pada lag 1 terdapat dua tanda bintang $\left(^{*}\right)$ pada SC dan HQ kemudian pada lag 2 terdapat tiga tanda bintang (*) pada LR, FPE dan AIC, maka dapat disimpulkan bahwa lag optimum berada pada lag 2 . Analisis selanjutnya adalah menguji model ARDL.

\section{Uji Model ARDL}

Pada uji stasioneritas telah diperoleh hasil bahwa data stasioner pada ordo yang berbeda yakni pada level dan first different namun tidak stasioner pada second different. Hal ini sudah sesuai dan memenuhi persyaratan dilakukannya pendekatan Autoregressive Distributed Lag (ARDL) dengan hasil model pada Tabel 5.

Tabel 4. Hasil Uji Lag Optimum

\begin{tabular}{crrrrrr}
\cline { 2 - 7 } Lag & LogL & LR & FPE & AIC & SC & HQ \\
\cline { 2 - 7 } 0 & -216.7317 & NA & 0.035977 & 8.026609 & 8.172597 & 8.083064 \\
1 & -100.3308 & 211.6381 & 0.000936 & 475665 & $5.105604^{*}$ & $757938^{*}$ \\
2 & -82.47971 & $29.85996^{*}$ & $0.000884^{*}$ & $408353^{*}$ & 5.622244 & 4.816445 \\
3 & -68.24929 & 21.73374 & 0.000966 & 472701 & 6.270544 & 5.106612 \\
4 & -57.24738 & 15.20263 & 0.001214 & 654450 & 7.036244 & 5.514180 \\
5 & -38.72428 & 22.90129 & 0.001199 & 562701 & 7.528446 & 5.648250
\end{tabular}

Sumber: data diolah peneliti, 2019 
Tabel 5. Model ARDL

\begin{tabular}{lllll}
\hline Method: ARDL & & & & \\
\hline $\begin{array}{l}\text { Model selection method: Akaike info criterion } \\
\text { (AIC) }\end{array}$ & & & & \\
Selected Model: ARDL(2, 0, 1, 0) & & & & \\
Variable & Coefficient & Std. Error & t-Statistic & Prob. \\
LNZIS(-1) & 0.376934 & 0.129340 & 2.914286 & 0.0053 \\
LNZIS(-2) & -0.200268 & 0.141489 & -1.415428 & 0.1630 \\
INFLASI & -0.357333 & 5.317900 & -0.067194 & 0.9467 \\
LNIPI & -0.287439 & 1.857056 & -0.154782 & 0.8776 \\
LNIPI(-1) & 669651 & 1.761291 & 2.594489 & 0.0123 \\
KURS & $-3.56 \mathrm{E}-05$ & 0.000109 & -0.326199 & 0.7456 \\
C & -1.484228 & 8.230247 & -0.180338 & 0.8576 \\
R-squared & 0.436991 & Mean dependent var & 22.96806 & \\
Adjusted R-squared & 0.370754 & S.D. dependent var & 0.535859 & \\
S.E. of regression & 0.425070 & Akaike info criterion & 1.239637 & \\
Sum squared resid & 9.214917 & Schwarz criterion & 1.488311 & \\
Log likelihood & -28.94947 & Hannan-Quinn criter. & 1.336501 & \\
F-statistic & 6.597443 & Durbin-Watson stat & 2.041726 & \\
Prob(F-statistic) & 0.000033 & & & \\
\hline
\end{tabular}

Sumber: data diolah peneliti, 2019

Metode pemilihan model dalam penelitian ini menggunakan nilai Akaike Info Criterion (AIC) yang menyatakan model ARDL yang terpilih adalah $(2,0,1,0)$, dengan demikian bentuk umum model ARDL $(2,0,1,0)$ yang akan diestimasi adalah sebagai berikut:

LNZIS $=\beta 1$ LNZISt $-1-\beta 2$ LNZISt $-2-$ $\beta$ INFLASIt- $1 \neg-\beta$ LLNIPIt- $1+\beta$ LLNIPIt- 2 $-\beta 6$ LNIPIt- $1+$ et

di mana:

$$
\begin{aligned}
\beta \mathrm{i} & : \text { koefisien parameter model yang } \\
& \text { diestimasi } \\
\text { et } & : \text { residual model } \\
\text { i } & : 1,2,3,4,5,6
\end{aligned}
$$

\section{Pengujian Kesesuaian Model ARDL}

\section{$(2,0,1,0)$}

Pengujian kesesuaian model ARDL yang terpilih perlu dilakukan agar model penelitian yang terbentuk tidak melanggar kaidah-kaidah ekonometrika dengan melalui pemeriksaan autokorelasi serta mengetahui stabilitas model (Zaretta \& Yovita, 20219). Tabel 6 menunjukkan hasil uji autokorelasi dalam penelitian ini yang dilakukan menggunakan uji Breusch-Godfrey Serial Correlation LM dengan menggunakan hipotesis:

$\mathrm{H}_{0}$ : tidak terdapat autokorelasi pada residual model ARDL $(2,0,1,0)$

$\mathrm{H}_{1}$ : terdapat autokorelasi pada residual model ARDL $(2,0,1,0)$

Tabel 6. Hasil Uji Autokorelasi

\begin{tabular}{llll}
\hline \multicolumn{4}{l}{ Breusch-Godfrey Serial Correlation LM Test } \\
\hline F-statistic & 0.989179 & Prob. F(2,49) & 0.3792 \\
$\begin{array}{l}\text { Obs*R- } \\
\text { squared }\end{array}$ & 2.250853 & $\begin{array}{l}\text { Prob. Chi- } \\
\text { Square(2) }\end{array}$ & 0.3245 \\
\hline
\end{tabular}

Sumber: data diolah peneliti, 2019

Hasil pengolahan uji autokorelasi pada Tabel 6 menunjukkan bahwa nilai pada p-value adalah 0,3245 lebih besar dari 5\% $(0,3245>0,05)$. Hal tersebut mengindikasikan bahwa pada tingkat kepercayaan 95\%, H0 tidak dapat ditolak. Artinya tidak terdapat 
autokorelasi pada residual model ARDL $(2,0,1,0)$. Selanjutnya, untuk mengetahui stabilitas model akan dilakukan uji Cusum dengan hasil pada Gambar 2.

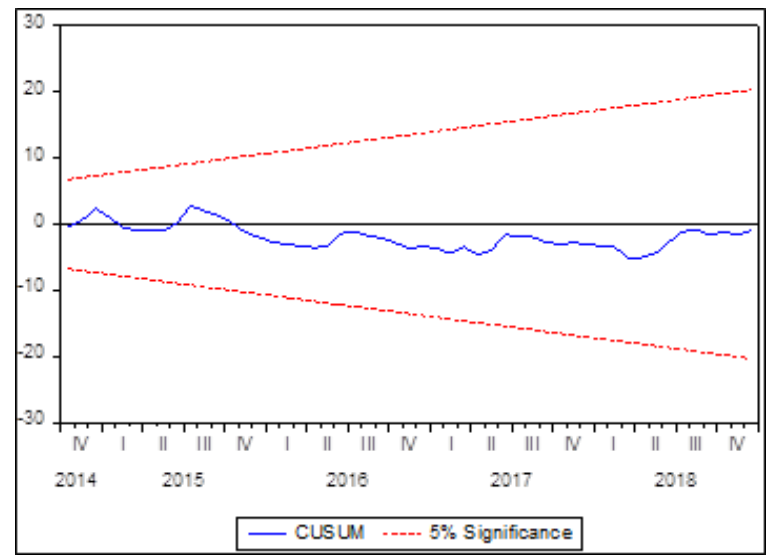

Gambar 2. Hasil Uji Cusum

Uji stabilitas model ARDL $(2,0,1,0)$ ditunjukkan pada Gambar 2 dengan derajat kepercayaan 95\%. Pada uji Cusum, stabilitas model dapan dilihat melalui garis Cusum yang berwarna biru, sedangkan garis putus-putus merah menunjukkan tingkat signifikansi 5\%.
Gambar 2 menunjukan bahwa garis Cusum berada di antara garis signifikan 5\% yang membuktikan bahwa model ARDL $(2,0,1,0)$ stabil. Selanjutnya akan dilakukann pengujian kointegrasi dengan menggunakan Bounds test.

\section{Uji Kointegrasi}

Bounds Test dilakuan untuk mengetahui adanya long-run association dalam model ARDL yang terpilih. Hasil dari bounds test akan dilihat dari perbandingan nilai F-statistic dengan Pesaran Shin critical value pada level 5\%. Apabila F-statistic menunjukkan nilai lebih besar dari upper bounds value maka pada model ini variabel-variabel penelitian bergerak bersama-sama dalam jangka panjang. Apabila nilai F-statistic berada dibawah lower bound, maka dapat disimpulkan bahwa tidak terjadi kointegrasi. Namun apabila F-statistic berada diantara lower bound dan upper bound maka hasilnya adalah tidak dapat disimpulkan.

Tabel 7. Uji Kointegrasi Bound Test

\begin{tabular}{|c|c|c|c|c|}
\hline F-Bounds Test & \multicolumn{4}{|c|}{ Null Hypothesis: No levels relationship } \\
\hline Test Statistic & Value & \multicolumn{2}{|l|}{ Signif. } & $\mathrm{I}(1)$ \\
\hline & & & \multicolumn{2}{|c|}{ Asymptotic: $n=1000$} \\
\hline \multirow{4}{*}{$\begin{array}{l}\text { F-statistic } \\
\mathrm{k}\end{array}$} & 5.589719 & $10 \%$ & 2.37 & 3.2 \\
\hline & 3 & $5 \%$ & 2.79 & 3.67 \\
\hline & & $2.5 \%$ & 3.15 & 4.08 \\
\hline & & $1 \%$ & 3.65 & 76 \\
\hline \multirow[t]{8}{*}{ Actual Sample Size } & 58 & & \multicolumn{2}{|c|}{ Finite Sample: $\mathrm{n}=60$} \\
\hline & & $10 \%$ & 2.496 & 3.346 \\
\hline & & $5 \%$ & 2.962 & 3.91 \\
\hline & & $1 \%$ & 4.068 & 5.25 \\
\hline & & & \multicolumn{2}{|c|}{ Finite Sample: $\mathrm{n}=55$} \\
\hline & & $10 \%$ & 2.508 & 3.356 \\
\hline & & $5 \%$ & 2.982 & 3.942 \\
\hline & & $1 \%$ & 4.118 & 5.2 \\
\hline
\end{tabular}

Sumber: data diolah peneliti, 2019 
Hasil bounds test pada Tabel 7 menunjukan bahwa nilai F-statistic pada model ARDL adalah 5,589719 lebih besar dari nilai upper bounds pada level 10\%, $5 \%, 2,5 \%$ hingga $1 \%$. Hal ini membuktikan bahwa ketiga variabel dalam penelitian ini (inflasi, IPI, dan kurs) memiliki kointegrasi jangka panjang. Artinya ketiga variabel tersebut bergerak bersama-sama dalam jangka panjang.

\section{Estimasi Jangka Pendek}

Dari Tabel 5 dapat diketahui efek jangka pendek makroekonomi terhadap penghimpunan ZIS di BAZNAS Indonesia. Tabel 5 menunjukkan bahwa inflasi periode saat ini, kurs periode saat ini, memiliki hasil negatif tidak signifikan terhadap penghimpunan dana ZIS. Sedangkan IPI periode sebelumnya, memiliki hasil negatif signifikan terhadap penghimpunan dana ZIS pada tingkat $5 \%$.

Nilai R-squared pada penelitian ini memiliki angka 0,436991 yang berarti bahwa variabel inflasi, kurs, dan IPI dapat menjelaskan pengaruhnya terhadap penghimpunan dana ZIS sebesar 43,6\%.

\section{Estimasi Jangka Panjang}

Hasil estimasi model ARDL pada Tabel 8 menyatakan bahwa IPI memiliki dampak positif signifikan terhadap penghimpunan dana ZIS. Dapat dikatakan kuat dalam jangka panjang, sedangkan inflasi dan kurs memiliki dampak negatif dan lemah pada tingkat signifikansi $10 \%$.

\section{Pengaruh Inflasi terhadap Penghimpunan Dana ZIS di BAZNAS}

Hasil pengolahan data pada penelitian ini menunjukan bahwa inflasi berpengaruh tidak signifikan terhadap penghimpunan dana ZIS dengan probabilitas 0,9466 >0,05. Penelitian Hariyani dkk. (2018) menyatakan bahwa guncangan inflasi mampu menurunkan penghimpunan dana ZIS. Inflasi memiliki hubungan jangka panjang, namun dalam penelitian ini inflasi tidak memiliki pengaruh jangka pendek.

Tabel 8. Uji Jangka Pendek ARDL

\begin{tabular}{llllr}
\hline \multicolumn{1}{c}{ Variable } & \multicolumn{1}{c}{ Coefficient } & \multicolumn{1}{c}{ Std. Error } & t-Statistic & Prob. \\
\hline LNZIS(-1) & 0.376934 & 0.129340 & 2.914286 & 0.0053 \\
LNZIS(-2) & -0.200268 & 0.141489 & -1.415428 & 0.1630 \\
INFLASI & -0.357333 & 5.317900 & -0.067194 & 0.9467 \\
LNIPI & -0.287439 & 1.857056 & -0.154782 & 0.8776 \\
LNIPI(-1) & 669651 & 1.761291 & 2.594489 & 0.0123 \\
KURS & $-3.56 \mathrm{E}-05$ & 0.000109 & -0.326199 & 0.7456 \\
C & -1.484228 & 8.230247 & -0.180338 & 0.8576 \\
R-squared & 0.436991 & Mean dependent var & 22.96806 & \\
Adjusted R-squared & 0.370754 & S.D. dependent var & 0.535859 & \\
S.E. of regression & 0.425070 & Akaike info criterion & 1.239637 & \\
Sum squared resid & 9.214917 & Schwarz criterion & 1.488311 & \\
Log likelihood & -28.94947 & Hannan-Quinn criter. & 1.336501 & \\
F-statistic & 6.597443 & Durbin-Watson stat & 2.041726 & \\
Prob(F-statistic) & 0.000033 & & & \\
\hline er: data diolah peneliti, 2019 & & &
\end{tabular}

Sumber: data diolah peneliti, 2019 
Tabel 9. Hasil Estimasi Jangka Panjang

\begin{tabular}{lllll}
\hline Variable & Coefficient & Std. Error & t-Statistic & Prob. \\
\hline INFLASI & -0.434008 & 6.451574 & -0.067272 & 0.9466 \\
LNIPI & 5.201065 & 2.264328 & 2.296957 & 0.0258 \\
KURS & $-42 \mathrm{E}-05$ & 0.000134 & -0.321868 & 0.7489 \\
C & -1.802705 & 10.05651 & -0.179258 & 0.8584 \\
\hline
\end{tabular}

Sumber: data diolah peneliti, 2019

\section{Pengaruh Indeks Produksi Industri terhadap Penghimpunan Dana ZIS di BAZNAS}

Hasil pengolahan data dalam penelitian ini menunjukkan adanya pengaruh signifikan antara IPI terhadap penghimpunan dana ZIS periode 2014-2018. Hal ini ditunjukkan dengan koefisien dari LNIPI sebesar 5,201065 dengan nilai positif menjelaskan bahwa bila perubahan pertumbuhan IPI naik 1\%, maka akan terjadi penurunan meningkatnya penghimpunan dana ZIS 5,201065\%.

Perkembangan pada sektor riil sangatlah mempengaruhi berbagai aspek, salah satunya yakni penghimpunan dana ZIS, di mana pertumbuhan IPI merupakan proksi dari pertumbuhan ekonomi yang secara tidak langsung mempengaruhi tingkat pendapatan nasional. Hal tersebut juga akan berkaitan dengan pendapatan masyarakat serta mempengaruhi kemampuan masyarakat untuk membayarkan zakat ataupun mau berinfak dan bersedekah. Melihat penelitian sebelumya yang dilakukan oleh Hariyani dkk. (2018), penelitian ini mendukung tentang adanya pengaruh signifikan antara Indeks Produksi Industri terhadap penghimpunan dana ZIS. Hariyani dkk. (2018) juga menjelaskan tentang pentingnya pengelolaan dana ZIS secara optimal pada sektor produksi dengan tujuan untuk memberikan dampak positif terhadap penerimaan dana ZIS.

\section{Pengaruh Kurs terhadap Penghimpunan Dana ZIS di BAZNAS}

Hasil pengolahan data dalam penelitian ini menunjukkan adanya pengaruh tidak signifikan antara kurs terhadap penghimpunan dana ZIS periode 2014-2018, yang ditunjukkan dengan koefisien dari kurs 3,56. Sedangkan pada hasil penelitian Dwitama \& Widiastuti (2016) bahwa kurs dolar berpengaruh tidak signifikan terhadap jumlah zakat pada lembaga Amil Zakat di Dompet Dhuafa dari periode 19972013. Hasil ini sejalan dengan penelitian yang juga memiliki hasil bahwa kurs tidak signifikan terhadap penghimpunan dana ZIS. Meningkatnya nilai tukar dolar terhadap rupiah akan juga meningkatkan pendapatan masyarakat yang memiliki penghasilan dalam bentuk dolar. Hal ini membuat zakat naik karena jumlah yang harus dikelauarkan akan bertambah sesuai dengan pendapatan yang dihasilkan. Oleh karenanya, nilai tukar atau kurs tidak mempunyai pengaruh signifikan terhadap penghimpunan jumlah zakat.

Melemahnya nilai tukar rupiah terhadap dolar tidak lepas dari yang disebut free floating exchange rate system atau sistem nilai tukar mengambang yang diterapkan pada perekonomian Indonesia. Dalam pandangan Islam, sistem ekonomi dalam nilai tukar adalah nilai tukar tetap yang akan menjadikan kestabilan dalam perekonomian sehingga terciptalah kesejahteraan masyarakat. 
Pengaruh Inflasi, Indeks Produksi Industri, dan Kurs terhadap... (Dina Islamiyati, Ira Humaira Hany)

\section{SIMPULAN DAN SARAN}

Penelitian ini memiliki tujuan untuk melihat hubungan natara kurs (nilai tukar rupiah), inflasi, dan Indeks Produksi Industri terhadap penghimpunan dana ZIS periode tahun 2014-2018 dengan menggunakan pendekatan Autoregressive Distribusi Lag (ARDL). Dari hasil penelitian menunjukkan bahwa hanya variabel IPI yang berpengaruh signifikan terhadap penghimpunan dana ZIS dengan melihat nilai probabilitas sebesar 0,0123 . Dengan nilai koefisien 4,569651 dengan nilai positif menjelaskan bahwa bila perubahan pertumbuhan IPI naik $1 \%$, akan terjadi penurunan meningkatnya penghimpunan dana ZIS 4,569651\%. Sedangkan variabel inflasi dan kurs berpengaruh tidak signifikan. Namun, semua variabel memiliki kointegrasi jangka panjang atau bergerak bersama-sama dalam jangka panjang dengan melihat hasil dari nilai F-statistic yang lebih besar dari upper bounds.

Meningkatnya IPI berpengaruh terhadap jumlah penghimpunan dana ZIS di mana hal ini tidak terlepas dari meningkatnya produksi industri sehingga dibutuhkanlah kontribusi pekerja untuk memenuhi kebutuhan produksinya yang nanti akan juga mempengaruhi pendapatan pekerja tersebut.

\section{REFERENSI}

Aziz, H. A., Widiastuti, T., Mawardi, I., Herianingrum, S., Ryandono, M. N. H., Ratnasari, R. T., Hapsari, M. I., Faizah, S. I., Kusuma, K. A., Mintarti, N., Haryono, A. R., \& Murniati, M. (2017). Indonesia Zakat Development Report: Zakat dan Pemberdayaan. Surabaya: Airlangga University Press.

Badan Pusat Statistik (2019). Persentase penduduk miskin menurut provinsi. https://www.bps.go.id/ dynamictable/2016/08/18/1219/

persentase-penduduk-miskinmenurut-provinsi-2007---2019.html. Diakses pada 11 Maret 2019.

Badan Pusat Statistik (2019). Kemiskinan dan ketimpangan. https://www.bps. go.id/subject/23/kemiskinan-danketimpangan.html. Diakses pada 11 Maret 2019.

Del Rosa, Y., Agus, I., \& Abdilla, M. (2019). Pengaruh Inflasi, Kebijakan Moneter dan Pengangguran Terhadap Perekonomian Indonesia. Jurnal Ekonomi dan Bisnis Dharma Andalas, 21(2), 183-293.

Dwitama, R. B., \& Widiastuti, T. (2016). Pengaruh Indikator Makro Ekonomi: Infasi Dan Nilai Tukar Rupiah Terhadap Jumlah Zakat Terkumpul Di Lembaga Amil Zakat Dompet Dhuafa Periode 1997-2013. Jurnal Ekonomi Syariah Teori dan Terapan, 3(7), 584.

Hariyani, H. F., Zuhroh, I., \& Malik, N. (2018). Guncangan variabel makroekonomi terhadap penerimaan ZIS di BAZNAS pusat. Seminar Nasioinal dan Call for Paper III Fakultas Ekonomi, 167-179.

Isnan, A. (2017). Analisis Pengaruh Ekspor Netto, Kurs, Dan Indeks Produksi Industri Terhadap Pertumbuhan Ekonomi Indonesia Tahun 2005-2015. Skripsi. Fakultas Ekonomi Dan Bisnis UIN Syarif Hidayatullah Jakarta.

Prakoso, B. (2007). Korelasi Antara Variabel Ekonomi Makro dengan Jakarta Islamic Index dan Indeks Harga Saham gabungan di Bursa Efek Jakarta (periode 2001-2005). Tesis. Program Magister Manajemen Universitas Indonesia.

Rumate, V. A., \& Engka, D. S. (2019). Pengaruh Tingkat Inflasi, Investasi, Pertumbuhan Ekonomi dan Tingkat Pengangguran Terhdap Tingkat Kemiskinan di Provinsi Sulawesi Utara. Jurnal Pembangunan Ekonomi Dan Keuangan Daerah, 19(3). 
Susanto, E., Rochaida, E., \& Ulfah, Y. (2018). Pengaruh inflasi dan pendidikan terhadap pengangguran dan kemiskinan. Inovasi, 13(1), 19-27.

Tanjung, H., \& Devi, A. (2018). Metodologi Penelitian Ekonomi Islam. Bekasi: Gramata Publishing.

Triyono. (2008). Analisis Perubahan Kurs Rupiah Terhadap Dollar Amerika. Publikasi Ilmiah Universitas Muhammadiyah Surakarta, 9(2), 156167.

Tulak, D. Y., Junaidi, J., \& Utami, I. T. (2017). Penerapan Autoregressive Distributed Lag (ARDL) Dalam Memodelkan Pengaruh Indeks Harga Konsumen (IHK) Kelompok Bahan Makanan Dan Kelompok Makanan Jadi Terhadap Inflasi di Kota Palu. Natural Science: Journal of Science and Technology, 6(3).

Zaretta, B., \& Yovita, L. (2019). Harga Saham, Nilai Tukar Mata Uang dan Tingkat Suku Bunga Acuan Dalam Model Autoregressive Distributed Lag (ARDL). Jurnal Penelitan Ekonomi dan Bisnis, 4(1), 9-22. 